\title{
sciendo
}

DOI: $10.2478 / f v-2020-0015$

\section{PROTECTIVE EFFECT OF FLAXSEED ON THE HEALTH OF EXPERIMENTAL ANIMALS EXPOSED TO XYLENE}

\author{
Kuráňová, E., Andrejčáková, Z., Vlčková, R., Sopková, D. \\ Department of Anatomy, Histology and Physiology, Institute of physiology \\ University of Veterinary Medicine and Pharmacy in Košice, Komenského 73, 04181 Košice \\ Slovakia
}

zuzana.andrejcakova@uvlf.sk

\begin{abstract}
Xylene is mainly used as a solvent in the printing, tire and leather industries. It is also used as: a facility cleaner, paint and varnish thinner, component of fuel, and chemical for the laboratory processing of histological preparations. For these reasons people are frequently exposed to xylene and the risk of intoxication is high. This study focused on the protective effect of flaxseed on mice experimentally intoxicated with xylene. The experiment lasted 14 days. The mice used in this study $(n=60)$ were allocated to 3 groups: the control group (C) received only the standard diet; the xylene group $(\mathrm{X})$ was fed a standard diet and was administered xylene p.o. $(10 \mu \mathrm{l}$ daily); and the xylene + flaxseed group (XF) received the standard feed, crushed flaxseed and xylene at the same dose as group $\mathrm{X}$. The observations involved changes in: body weight, liver enzyme levels, and caspase activity in the liver of the mice. The administration of additives resulted in significant changes in the body weight of the mice on day 7 of the experiment $(P<0.05)$. The highest weight gain was observed in mice from the XF group. In contrast,
\end{abstract}

the body weight of the mice from group $\mathrm{X}$ exposed only to xylene was the lowest. The biochemical analysis of the liver cells of the xylene intoxicated mice showed elevated levels of: aspartate aminotransferase (AST), De Ritis ratio (AST/ALT ratio), and lactate dehydrogenase isoenzymes LDH-3 and LDH-5. Caspase-3, the marker of apoptosis, was increased in the XF group. Thus, the administration of flaxseed in our experiment had a beneficial effect on the clinical and metabolic parameters of mice intoxicated with xylene. Our results indicated that the administration of flaxseed, may act as a preventative measure with respect to xylene intoxication of animals; however, further analyses are needed to confirm this assumption.

Key words: crude oil; flaxseed; lactate dehydrogenase; mouse; xylene

\section{INTRODUCTION}

Crude oil is used in various branches of industry. Together with its side products it is used for: production of 
fuel, plastic materials, acrylates, dyes, cleaning preparations, textile fibres, pesticides, and other auxiliary compounds intended for industrial use. Crude oil extraction presents also considerable environmental risks [20]. It contributes to air pollution, acid rains, damage to the ozone layer, and the development of various diseases in humans and other animals. Currently, many scientists point to the absence of studies leading to an accurate definition of the harmful effects of crude oil and its intermediate products, for example xylene, on humans or other animals living close to oil wells. Xylene is a chemical the scientists and laboratory workers are frequently exposed to during the processing of some laboratory samples [6]. It is necessary to improve the control of many contaminants in the environment, for example in air, water and soil and focus on the prevention of their harmful effects.

Current research focuses on the utilization of biologically active additives of natural origin that may protect or improve the health of consumers. Such additives include also flaxseed. The curative effects of common flax (Linum usitatissimum) have been described in studies that investigated the development of: gastrointestinal diseases, prevention of diabetes, cardiovascular diseases, atherosclerosis and hypertension [34]. Flax is a rich source of n-3 polyunsaturated fatty acids (PUFA), particularly the essential $\alpha$-linolenic acid (ALA). The n- 6 and n-3 PUFA are an integral parts of cell membranes and are responsible for their fluidity and other physicochemical properties. Ko m prda [23] reported that for the maintenance of good health of humans, the n-6:n-3 ratio in their nutrition should be as close as possible to $1: 1$. In the advanced countries the food generally contains more $n-6$ and very little of n-3 PUFAs which is considered as one of the reasons for the high prevalence of chronic and degenerative diseases [7]. Enzymatic oxidation of n-3 PUFAs produces eicosanoids which act as tissue hormones participating in reproductive, immune, secretory and growth processes. In the intestine, under the action of microorganisms, the processes of dihydroxylation, dehydrogenation and demethylation transform lignans to enterolacton and enterodiol that pass through the intestinal wall and are absorbed into the blood and tissues [14, 38]. The chemical structure of these compounds resembles that of $17 \beta$-oestradiol. They bind to oestrogen receptors of target cells and support cellular proliferation and apoptosis [32] and some other factors affecting the cellular cycle $[29,41]$. Under both in vitro
[21] and in vivo [36] conditions, flax promotes apoptosis of somatic cells of ovaries and oocytes in pigs. Some studies have confirmed the pro-apoptotic effect of flax related to the high content of antioxidants, such as flavonoids [17]. Another effect of n-3 PUFA is related to their action at the level of cell membranes involving the regulation of the flow of potassium ions into the cells (cervonic acid) [26]. One of the ways of evaluation of the integrity of cell membranes is the determination of the activity of lactate dehydrogenase $(\mathrm{LDH})$, an enzyme found in all organs and tissues including animal blood $[4,22]$. Its increased or decreased release into the environment is considered a valuable marker of the integrity and viability of cells [25].

The aim of this study was to obtain new knowledge about the influence of flaxseed on mice experimentally intoxicated with xylene under in vivo conditions.

\section{MATERIALS AND METHODS}

\section{Experimental animals and groups}

This study was carried out using 60 female mice of line CD-1 ICR (Velaz, Czechia). Before the onset of the experiment, at the age of 28 days, these mice were transferred from the breeding establishment to the quarantine section of the experimental facility of the Institute of Physiology of Farm Animals of the Slovak Academy of Science in Košice. After reaching the age of 35 days, they were divided to three groups with 20 mice in each: group 1 (control-C) the mice were fed the standard commercial feed (M3; BONAGRO a.s. Blažovice CZ, Czechia; Table 1) at a dose of $4 \mathrm{~g}$ per day (in two feedings); group 2 (xylene-X) was fed the standard diet and administered xylene p.o. $\left(10 \mu\right.$ l.day ${ }^{-1}$ by cannula); and group 3 (xylene and flaxseed XF) was fed the standard diet supplemented with crushed flaxseed (var. Libra, $10 \%$ concentration in the feed) and administered xylene at the same dose as group 2. The experiment lasted 14 days. The mice were kept in boxes (6-7 mice in each) on bedding (Lignocel 3-4S), at a temperature of $20-24^{\circ} \mathrm{C}$, relative humidity of $45-65 \%$ and a 12 -hour light regimen. Their weight was regularly recorded. After 14 days, they were sacrificed by cervical dislocation (Experiment approval No.598/18-221/3) and their livers were collected for analysis of: alanine transferase (ALT), aspartate aminotransferase (AST), activity of lactate dehydrogenase (LDH) and its isoenzymes and the activity of caspase. 
Table 1. Composition of the standard diet M3

\begin{tabular}{lc|lc}
\hline Crude protein & $22 \%$ & Vitamin A & $20000 \mathrm{IU}$ \\
Crude fibre & $3.14 \%$ & Ferrous sulphate monohydrate & $17000 \mathrm{mg}$ \\
Coarse fat & $3.31 \%$ & Potassium iodide & $0.65 \mathrm{mg}$ \\
Ash & $6.16 \%$ & Cobalt (bis)carbonate & $0.4 \mathrm{mg}$ \\
Calcium & $1.01 \%$ & Copper sulphate pentahydrate & $15000 \mathrm{mg}$ \\
Phosphorus & $0.53 \%$ & Manganese oxide & $45000 \mathrm{mg}$ \\
Sodium & $0.11 \%$ & Zinc oxide & $71000 \mathrm{mg}$ \\
Vitamin D3 & $2000 \mathrm{IU}$ & Selenium & $0.15 \mathrm{mg}$ \\
\hline
\end{tabular}

\section{Spectroscopic analyses}

The spectroscopic analyses were carried out employing a spectrophotometer ALIZÉ (LISABIO, Pouilly-enAuxois, France). We applied $30 \mu \mathrm{l}$ of a sample and made it up to $500 \mu \mathrm{l}$ with a substrate. This method was used to determine: the total proteins (necessary for recalculation of the specific activity of enzymes), the concentration of alanine aminotransferase (ALT), aspartate aminotransferase (AST), and the activity of the total lactate dehydrogenase (TLDH).

\section{Electrophoretic analysis of lactate dehydrogenase isoenzymes}

The LDH isoenzymes were determined in the liver extracts. The samples were processed using an automatic, multiparametric, electrophoretic system HYDRASYS (SEBIA, Lisses, France). Dry gels were evaluated visually and densitometrically ( $\lambda 570 \mathrm{~nm}$; EPSON PERFECTION V 700 PHOTO) and the individual fractions were quantified using a software PHORESIS (Version 5.50, 2009, SEBIA, Lisses, France).

\section{Caspase activity}

The western blot analysis was performed using the supernatants of the liver extracts prepared for electrophoresis. We used $5 \%$ defatted milk in TBST (1M Tris- $\mathrm{HCl}$ s pH 7.5, $1 \mathrm{M} \mathrm{NaCl}, 0.01 \%$ Tween 20) to block the non-specific binding of the antibodies. After the migration of proteins in a polyacrylamide gel, we applied primary monoclonal antibodies (anti-caspase 3 antibody) using a 1:1000 dilution (Santa Cruz Biotechnology Inc., Dallas, USA) and incubated the gels overnight at $4{ }^{\circ} \mathrm{C}$. On the second day, we applied secondary anti-mouse IgG antibodies using 1:20 000 dilution (Sigma-Aldrich). The $\beta$-actin antibodies diluted 1:10 000 (Thermo-Fisher) were applied as a control. The reaction on the PVDF membrane was visualised by means of a chemiluminescence kit (Clarity ${ }^{\mathrm{TM}}$ Western ECL Blotting Substrate, Biorad) and scanned by an instrument Fusion-Fx7-Spectra (Vilber Lourmat, Eberhardzell, Germany).

\section{Statistical processing of the results}

The results obtained in our study were processed by a software GraphPad Prism 5.0 for Windows (GraphPad Software, San Diego, California, USA). An unpaired t-test was used to determine the significance of differences between groups at the end of the experiment. Our results were presented as arithmetic means and the standard errors of means (Mean \pm SEM). We found significant differences at the following levels: $\mathrm{P}<0.05 ; \mathrm{P}<0.01 ; \mathrm{P}<0.001$.

\section{RESULTS AND DISCUSSION}

Due to the intoxication with side products of the crude oil industry, the prevalence of various diseases of humans and other animals has increased recently. One of the potential preventive measures involves the use of natural additives including the common flax. This plant has beneficial effects on the health of individuals. Common flax was put to use in people with gastrointestinal problems, for example with constipation, colitis or enteritis, owing to its high content of fibres and other components [8]. Flaxseed has also been used in the treatment of cardiovascular dis- 
eases, atherosclerosis and hypertension $[1,12]$. It supports the treatment of acne and diabetes, it is used to alleviate the symptoms of menopause and helps to manage obesity. Beneficial effects of flax include the prevention of cancer of the mammary gland, prostate, lungs and the colon [9, $10,37,39]$.

Our experiment involved 14-day observation of mice allocated to three groups subjected to different treatments. The body weight of mice fed the standard diet and exposed to xylene p.o. (X) was reduced the most throughout the experiment (Fig. 1). Similar results were reported in the toxicological review by United States Environmental Protection Agency (US EPA) in which the mice intoxicated with o-xylene showed a reduction in weight gain by about $15 \%$ during 6 or 12 months of administration of xylene [35]. By day 7 of our experiment, a significantly higher body weight $(\mathrm{P}<0.05)$ compared to group $\mathrm{X}$ was observed in mice from group XF, the diet that was supplemented with flaxseed ( $10 \%$ concentration in the feed) and also exposed to xylene (Fig. 1). The increased body weight after supplementation of flax was also observed by J u á r e z et al. [19]. On the other hand, Mohammadi-Sartang et al. [30] and P o urjafari et al. [31] recorded decreased body weight in humans who consumed flaxseed at doses $\geq 30 \mathrm{~g}$ for $\geq 12$ weeks.

The increased serum levels of the amino transferases ALT and AST indicated an acute or chronic damage to the liver. The increased AST also suggested a non-specific damage to tissues including: the liver, brain, pancreas, heart, kidneys, lungs and skeletal muscles. The AST levels determined in the liver cells of mice from group $\mathrm{X}$ were significantly higher $(\mathrm{P}<0.05)$ in comparison with the group XF supplemented with flaxseed (Fig. 1). This indicated some damage to the liver parenchyma of the mice. The increased activities of AST and ALT after the inhalation exposure to xylene were recorded by $\mathrm{K}$ ü k n e r et al. [24]. Similar to our experiment, the positive effects of flaxseed supplementation of the diet toward normalizing the levels of AST and ALT enzymes were described in the studies by A l - B i s h r i [2] and Z h a ng et al. [42].

The De Ritis ratio (serum AST/ALT ratio) indicated the degree of necrotic or other damage to the liver cells. The higher the coefficient, the more severe damage to the liver parenchyma is expected. In people this value must not exceed 1.0. The increase in this parameter indicated various pathological changes: AST/ALT $\leq 1$ indicated viral hepatitis, AST/ALT > 2 cirrhosis (any aetiology); and AST/ ALT $>4$ acute liver failure [28]. The maximum in mice is 1.38 [13]. In our experiment, this coefficient was increased in group X (Fig. 1) which indicated the hepatotoxic effect of xylene. In the control $\mathrm{C}$ and $\mathrm{XF}$ groups, this parameter was in the physiological range $(<1.38)$ which suggested the hepatoprotective effect of flaxseed.

The determination of the activity of lactate dehydrogenase in the serum has a broad clinical significance. Changes in the activity of LDH in cells and tissues have been considered a valuable marker of damage to cellular membranes, for example by xylene. We determined the activity of LDH in the extracts of liver homogenates. The LDH is an intracellular enzyme that after release to the surrounding environment indicates damage to tissues $[4,5,22,40]$. The activity of the total lactate dehydrogenase in the liver sample extracts was higher in groups $\mathrm{X}$ and $\mathrm{XF}$ in comparison to the control group $\mathrm{C}$, although the difference was insignificant (Fig. 2). The ability of flax oil to decrease the activity of serum LDH was observed in the study by $\mathrm{H}$ u s s e in et al. [18]. Polyunsaturated fatty acids originating from flax are capable of incorporating in cellular membranes and affecting their fluidity and other properties by means of the modulation of the phospholipid bilayer and changes in micro-domains that act as signal platforms regulating the transport of cholesterol, transduction of signals and endocytosis [27]. The increased intake of n-3 PUFAs can decrease the level of cholesterol in the body $[16,33]$ and its content in cellular membranes which can result in an increased incorporation of n-3 PUFAs and changes in the composition of membrane phospholipides [16].

The determination of the dominant isoenzyme allows one to identify the damaged organ. The isoenzyme LDH-1 is found particularly in the heart, erythrocytes and brain. Isoenzyme $\mathrm{LDH}-2$ is present in leucocytes and in lower proportion than LDH-1 also in erythrocytes. The LDH-3 isoform is typically associated with the lung tissue. Isoenzyme LDH-4 has been detected in kidneys, pancreas, and lymphatic nodules; and LDH-5 presence is characteristic of the liver and skeletal muscles [15]. Our study showed significant differences in the levels of isoenzymes LDH-3 and LDH-5 $(\mathrm{P}<0.05)$, and the LDH-5 isoenzyme was the one that indicated damage to the liver in the group exposed to xylene. On the other hand, the group XF that was fed also flaxseed showed a decrease in the concentration of these isoenzymes in comparison with group $\mathrm{X}$ which in- 

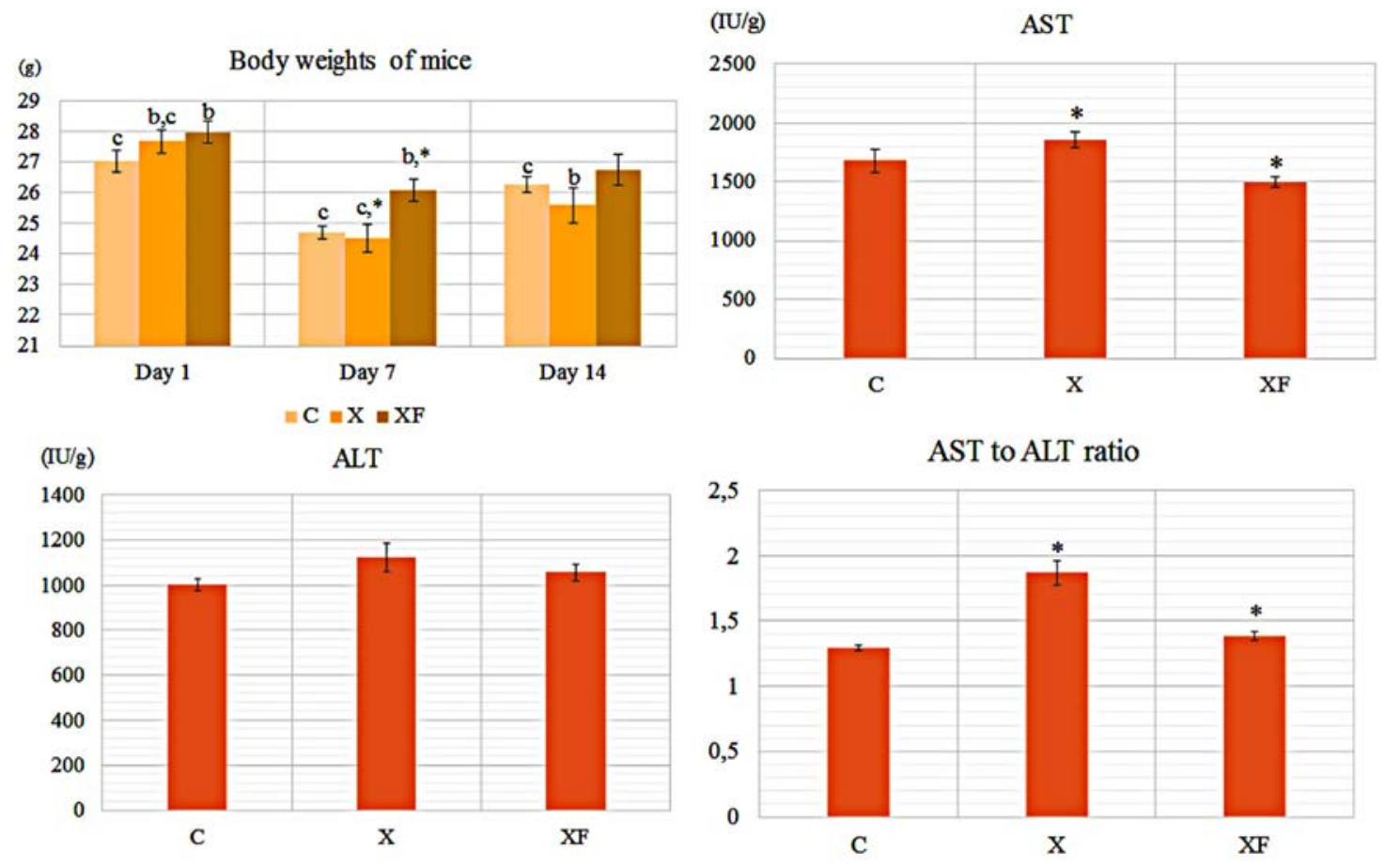

Fig. 1. Body weight changes, activity of AST and ALT enzymes and their ratio in control and experimentally intoxicated mice C-control; X-xylene; XF-xylene and flaxseed. The results (mean \pm SEM) marked with the same superscripts b, ${ }^{*}{ }^{\star}$ are statistically significant; superscripts b,c express dynamics of changes within the group and asterix * expresses significance of differences between the groups at the end of the experiment: ${ }^{*}=\mathrm{P}<0.05 ; \mathrm{b}=\mathrm{P}<0.01 ; \mathrm{c}=\mathrm{P}<0.001$

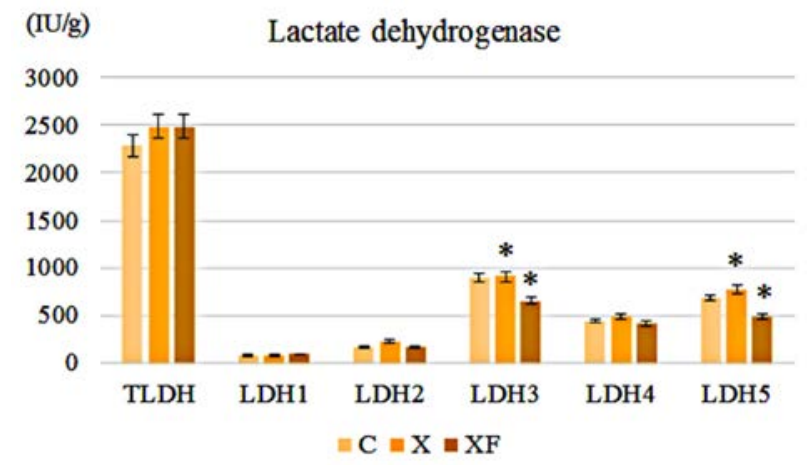

Caspase 3

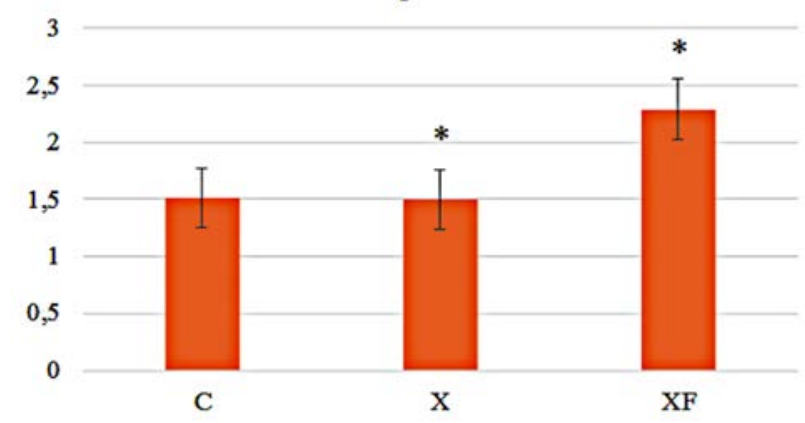

Fig. 2. Activity of total lactate dehydrogenase and its isoenzymes and intensity of immunoreaction (optical density) of caspase 3 in the liver of mice

$\mathrm{C}-$ control; $\mathrm{X}-\mathrm{xylene}$ XF-xylene and flaxseed. The results (Mean \pm SEM) marked with asterisk differed significantly $(\mathrm{P}<0.05)$ dicated a hepatoprotective effect of flaxseed supplementation. These results agree with those presented in the study by A n d rej čá k o vá et al. [5] in which the diet supplemented with flaxseed affected the release of the same isoenzymes (LDH-3 and LDH-5).

Our study included the observation of caspase 3 as a marker of apoptotic changes in the liver of intoxicated mice. Apoptosis is the main mechanism for the elimination of useless cells during development and maintenance of homeostasis in the healthy tissue. Thus, dysfunction of the apoptotic system results in pathogenesis of various diseases including cancer [17]. Our experiment revealed an increased expression of caspase 3 in group XF (Fig. 2), i. e. the group fed the diet fortified with flaxseed, in comparison with group $\mathrm{X}(\mathrm{P}<0.05)$ or the control. These results indicated the pro-apoptotic effect of supplementation of the diet with flaxseed on intoxicated hepatic cells. Similar results were obtained in the study conducted by A 1 - G h a $\mathrm{m} \mathrm{d}$ i et al. [3] who reported that the long-term exposure to organic solvents xylene or toluene was associated with apoptosis of cells in the proximal renal tubules that could lead to their failure. Our observations of the 
intoxicated mice, support the theory that the flaxseed oil may cause specific inhibition of the growth of tumorous cells and induce apoptosis of some tumour cells and thus exhibit anti-cancerous therapeutic potential [11].

\section{CONCLUSIONS}

The supplementation of diets with flaxseed of mice experimentally intoxicated with xylene resulted in a positive influence on their weight gain and selected biochemical parameters. We recorded a gradual increase in the body weight of mice that were fed flaxseed in comparison with the control group of animals. Thee supplementation of flaxseed alleviated the effects of intoxication which was reflected in the decreased activity of: the AST enzyme, De Ritis index, concentration of $\mathrm{LDH}$ and its isoenzymes LDH-3 and LDH-5 and of caspase 3 as a marker of apoptotic changes.

\section{ACKNOWLEDGEMENT}

This study was supported by the projects VEGA No. 1/0204/20 and 1/0392/17.

\section{REFERENCES}

1. Adkins, Y., Kelley, D. S., 2010: Mechanisms underlying the cardioprotective effects of omega-3 polyunsaturated fatty acids. J. Nutr. Biochem., 21, 781-792. DOI: 10.1016/j.jnutbio. 2009.12.004.

2. Al-Bishri, W. M., 2013: Favourable effects of flaxseed supplemented diet on liver and kidney functions in hypertensive Wistar rats. J. Oleo. Sci., 62, 9, 709-715. DOI: 10.5650/ jos.62.709.

3. Al-Ghamdi, S., Raftery, M., Yaqoob, M., 2003: Organic solvent-induced proximal tubular cell toxicity via caspase-3 activation. J. Toxicol. Clin. Toxicol., 41, 7, 941-945. DOI: 10. 1081=CLT -120026515 .

4. Andrejčáková, Z., Sopková, D., Vlčková, R., Kulichová, L., Gancarčíková, S., Almášiová, V., et al., 2016: Synbiotics suppress the release of lactate dehydrogenase, promote nonspecific immunity and integrity of jejunum mucosa in piglets. Anim. Sci. J., 87, 9, 1157-1166. Epub 2015, Dec. 21. DOI: 10. 1111/asj.12558.
5. Andrejčáková, Z., Sopková, D., Vlčková, R., Hertelyová, Z., Gancarčíková, S., Nemcová, R., 2019: The application of Lactobacillus reuteri CCM 8617 and flaxseed positively improved the health of mice challenged with enterotoxigenic E. coli O149:F4. Probiotics Antimicrob. Proteins, In press. DOI: $10.1007 / \mathrm{s} 12602-019-09578-\mathrm{x}$.

6. Bancroft, J., 2008: Theory and Practice of Histological Techniques. Elsevier Health Sciences, 725 pp.

7. Bassett, C. M., Rodriguez-Leyva, D., Pierce, G. N., 2009: Experimental and clinical research findings on the cardiovascular benefits of consuming flaxseed. Appl. Physiol. Nutr. Metab., 34, 5, 965-974. DOI: 10.1139/H09-087.

8. Bomba, A., Jonecová, Z., Koščová, J., Nemcová, R., Gancarčíková, S., Mudroňová, D., et al., 2006: The improvement of probiotics efficacy by synergistically acting components of natural origin. Biologia, 61, 6, 729-734. DOI: 10.2478/s11756-006-0149-y.

9. Bomba, A., Brandeburová, A., Ričanyová, J., Strojný, L., Chmelárová, A., Szabadosová, V., et al., 2012: The role of probiotics and natural bioactive compounds in modulation of the common molecular pathways in pathogenesis of atherosclerosis and cancer. Biologia, 67, 1, 1-13. DOI: 10.2478/ s11756-011-0155-6.

10. Borovská, D., Nemcová, R., Gancarčíková, S., Koščová, J., 2013: The synbiotic effect of lactobacilli and flaxseed on selected intestinal microflora and organic acid levels in weaned piglets. Microbiology, 2, 10, 82-86.

11. Buckner, A., Buckner, C. A., Montaut, S., Lafrenie, R. M., 2019: Treatment with flaxseed oil induces apoptosis in cultured malignant cells. Heliyon, 5, 8, e02251. DOI: 10.1016/j. heliyon.2019.e02251.

12. Calder, P. C., 2006: N-3 polyunsaturated fatty acids, inflammation, and inflammatory diseases. Am. J. Clin. Nutr., 83, (Suppl. 6), 1505-1519. DOI: 10.1093/ajcn/83.6.1505S.

13. Charles River Laboratories International, 2011: CD- $1^{\circ}$ IGS Mice NOMENCLATURE: Crl:CD1(ICR): https://www.criver. com/sites/default/files/resources/CD1IGSMouseModelInformationSheet.pdf.

14. Clavel, T., Henderson, G., Alpert, C. A., Philippe, C., Rigottier-Gois, L., Dore, J., et al., 2005: Intestinal bacterial communities that produce active oestrogen-like compounds enterodiol and enterolactone in humans. Appl. Environ. Microbiol., 71, 10, 6077-6085. DOI: 10.1128/AEM.71.10.60776085.2005 .

15. Dasgupta, A. Wahed, A., 2014: Clinical chemistry, immunology and laboratory quality control. A Comprehensive Re- 
view for Board Preparation, Certification and Clinical Practice. 1st Edition, Elsevier, 504 pp.

16. Feller, S. E., 2008: Acyl chain conformations in phospholipid bilayers: a comparative study of docosahexaenoic acid and saturated fatty acids. Chem. Phys. Lipids, 153, 1, 76-80. DOI: 10.1016/j.chemphyslip.2008.02.013.

17. Ficková, M., Nagy, M., 2007: Apoptosis - programmed cell death, and plant metabolites (In Slovak). Chemické Listy (Chemical Letters), 101, 131-137.

18. Hussein, S. A., El Senosi, Y. A. F., Hussanien, M. R., Hammad, M. M. F., 2016: Evaluation of the protective role of flaxseed oil on inflammatory mediators, antioxidant defence system and oxidative stress of liver tissue in hypercholesterolemic rats. Int. J. Pharma. Sci., 6, 3, 1480-1489. http://ijps. aizeonpublishers.net/content/2016/3/ijps1480-1489.pdf.

19. Juárez, M., Dugan, M. E., Aldai, N., Aalhus, J. L., Patience, J. F., Zijlstra, R. T. et al., 2010: Feeding co-extruded flaxseed to pigs: Effects of duration and feeding level on growth performance and backfat fatty acid composition of grower-finisher pigs. Meat Sci., 84, 3, 578-584. DOI: 10.1016/j.meatsci.2009.10.015.

20. Kandyala, R., Raghavendra, S. P., Rajasekharan, S. T., 2010: Xylene: An overview of its health hazards and preventive measures. J. Oral. Maxillofac. Pathol., 14, 1, 1-5. DOI: 10. 4103/0973-029X.64299.

21. Kádasi, A., Štochmalová, A., Maruniaková, N., Kolesárová, A., Grossman, R., Sirotkin, A. V., 2016: Effect of natural plant extracts on porcine functions. J. Microbiol. Biotech. Food Sci., 4, 2, 45-48. DOI: 10.15414/jmbfs.2015.4.special2.45-48.

22. Kending, D. M., Tarloff, J. B., 2007: Inactivation of lactate dehydrogenase by several chemicals: Implications for in vitro toxicology studies. Toxicology in Vitro, 21, 125-132. DOI: 10.1016/j.tiv.2006.08.004.

23. Komprda, T., 2003: Basis of Human Nutrition (In Czech), 1st edn., Mendel's Agriculture and Forestry University in Brno, $162 \mathrm{pp}$.

24. Kükner, A., Canpolat, L., Ozan, E., Gökçimen, A., Ozan, S., Doğrul, M., 1997: The effect of xylene inhalation on the rat liver. Acta Physiol. Hung., 85, 3, 231-241.

25. Legrand, C., Bour, J. M., Capiaumont, J., Martial, A., Marc, A., Wudtke, M. et al., 1992: Lactate dehydrogenase (LDH) activity of the number of dead cells in the medium of cultured eukaryotic cells as marker. J. Biotechnol., 25, 231-243. DOI: 10.1016/0168-1656(92)90158-6.

26. Lombardi, F., Terranova, P., 2007: Antiarrhythmic properties of N-3 polyunsaturated fatty acids (n-3 PUFA). Curr. Med. Chem., 14, 2070-2080. DOI: 10.2174/092986707781368405.
27. Ma, D. W., Seo, J., Switzer, K. C., Fan, Y. Y., McMurray, D. N., Lupton, J. R. et al., 2004: n-3 PUFA and membrane microdomains: a new frontier in bioactive lipid research. $J$. Nutr. Biochem., 15, 11, 700-706. DOI: 10.1016/j.jnutbio. 2004.08.002.

28. Martín, M. G., Molina, A. Z., 2020: Transaminases: Valoración y significación clínica. Protocolos diagnóstico-terapéuticos de Gastroenterología, Hepatología y Nutrición Pediátrica SEGHNP-AEP. 267-275. https://www.aeped.es/sites/default/ files/documentos/transaminasas.pdf.

29. Ming, L. G., Chen, K. M., Xian, C. J., 2013: Functions and action mechanisms of flavonoids genistein and icariin in regulating bone remodeling. J. Cell Physiol., 228, 513-521. DOI: $10.1002 /$ jcp. 24158 .

30. Mohammadi-Sartang, M., Mazloom, Z., Raeisi-Dehkordi, H., Barati-Boldaji, R., Bellissimo, N., Totosy de Zepetnek, J. O., 2017: The effect of flaxseed supplementation on body weight and body composition: a systematic review and metaanalysis of 45 randomized placebo-controlled trials. Obes. Rev., 18, 9, 1096-1107. DOI: 10.1111/obr.12550.

31. Pourjafari, F., Haghpanah, T., Sharififar, F., NematollahiMahani, S. N., Afgar, A., Karam, G. A. et al., 2019: Protective effects of hydro-alcoholic extract of Foeniculum vulgare and Linum usitatissimum on ovarian follicle reserve in the first-generation mouse pups. Heliyon, 5, 10, e02540. DOI: 10. 1016/j.heliyon.2019.e02540.

32. Rietjens, I. M., Sotoca, A. M., Vervoort, J., Louisse, J., 2013: Mechanisms underlying the dualistic mode of action of major soy isoflavones in relation to cell proliferation and cancer risks. Mol. Nutr. Food Res., 57, 100-113. DOI: 10.1002/ mnfr.201200439.

33. Sopková, D., Hertelyová, Z., Andrejčáková, Z., Vlčková, R., Gancarčíková, S., Petrilla, V. et al., 2017: The application of probiotics and flaxseed promotes metabolism of n-3 polyunsaturated fatty acids in pigs. J. Appl. Anim. Res., 45, 1, 93-98. DOI: $10.1080 / 09712119.2015 .1124333$.

34. Szabadosová, V., Pramuková, B., Hijová, E., 2011: Flaxseed, the cancer's foe (In Slovak). Slovenský lekár (Slovak Doctor) $3-8$.

35. United States Environmental Protection Agency (US EPA), 2003: Toxicological Review of Xylenes (CAS No. 1330-20-7). In Support of Summary Information on the Integrated Risk Information System (IRIS), 106 pp. https://cfpub.epa.gov/ncea/ iris/iris_documents/documents/toxreviews/0270tr.pdf

36. Vlčková, R., Andrejčáková, Z., Sopková, D., Hertelyová, Z., Kozioł, K., Koziorowski, M., et al., 2018: Supplemental flax- 
seed modulates ovarian functions of weanling gilts via the action of selected fatty acids. Anim. Reprod. Sci., 193, 171-181. DOI: 10.1016/j.anireprosci.2018.04.066.

37. Wall, R., Ross, R. P., Fitzgerald, G. F., Stanton, C., 2010: Fatty acids from fish: the anti-inflammatory potential of long-chain omega-3 fatty acids. Nutr. Rev., 68, 5, 280-289. DOI: 10.1111/j.1753-4887.2010.00287.x.

38. Wang, L. Q., 2002: Mammalian phytoestrogens: enterodiol and enterolactone. J. Chromatogr. B Analyt. Technol. Biomed. Life Sci., 777, 1-2, 289-309. DOI: 10.1016/s15700232(02)00281-7.

39. Wang, D. F., Zhou, L. L., Zhou, H. L., Hou, G. Y., Zhou, X., Li, W., 2017: Effects of Piper sarmentosum extract on the growth performance, antioxidant capability and immune response in weaned piglets. J. Anim. Physiol. Anim. Nutr., 101, 1, 105-112. DOI: 10.1111/jpn.12517.
40. Wang, W., Liu, Y., Sun, M., Sai, N., You, L., Dong X. et al., 2019: Hepatocellular toxicity of paris saponins I, II, VI and VII on two kinds of hepatocytes-HL-7702 and HepaRG cells, and the underlying mechanisms. Cells, 8, 7, pii: E690. DOI: 10.3390/cells8070690.

41. Yanagihara, N., Zhang, H., Toyohira, Y., Takahashi, K., Ueno, S., Tsuitsui, M., et al., 2014: New insights into the pharmacological potential of plant flavonoids in the catecholamine system. J. Pharmacol. Sci., 124, 123-128. DOI: 10. 1254/jphs.13r17cp.

42. Zhang, X., Wang, H., Yin, P., Fan, H., Sun, L., Liu, Y., 2017: Flaxseed oil ameliorates alcoholic liver disease via anti-inflammation and modulating gut microbiota in mice. Lipids Health Dis., 16, 1, 44. DOI: 10.1186/s12944-017-0431-8.

Received March 23, 2020

Accepted April 27, 2020 